\title{
AN ANALYZIS OF ENGLISH NATIONAL EXAM: TEST OF ENGLISH PROFICIENCY FOR STUDENT
}

\author{
Uswatunnisa \\ uswatunnisa@stainmajene.ac.id \\ Sekolah Tinggi Agama Islam Negeri Majene
}

\begin{abstract}
The National Exam of 2019 is still one of the absorbed issues to discuss. The researcher brings the issue up because in a couple of years there might be no more National Exam since the new minister is more likely to believe that Exams are conventional so the issue of abolishing it is heating up again. The National Exam has become a standard evaluation made by the government for every school level. The English exam is an English proficiency test for students. Yet, the test consists of listening and reading comprehension only. The objectives of the study are to find out whether the questions tested are appropriate with the qualifications, criteria, and the goals of each competence. Then, the researcher analyzed the error of each question. The researchers applied the general method in assessing the English test referring to the Hakuta and Jacks (2009) guidelines. The researcher applied descriptive qualitative as the research design. The test is focused more on cognitive skills, especially in reading skills. The students are taught all four language skills in schools and are expected to be superior to all of them at least. The researcher finds some errors in the test such as the test directions are unclear. Then, the questions are compiled disorderly and the amount of questions for each language competence is not equal. The test is not appropriate with the language learning objectives and so does with the language mastery demands.
\end{abstract}

Keywords: English Test, National Exam, Curriculum, Proficiency.

\section{INTRODUCTION}

Indonesia is one of countries that implements the National Exam every year. It is a standard evaluation system made by the government for every school level, starts from elementary school till high school level. Few years ago, the result score of the National Exam was used as the basis term to decide if the students were able to graduate from school or not. But, nowadays the rules has changed. Based on the decree of the minister (Article 1, Section 6) year 2010 says that the score of the National Exam is one of terms of students' graduation standards and there should be an accumulation score of both the National and the School's Exams' scores.

The English National Exam is one of language tests. The test consists of two language skills such as listening and reading comprehension as well as the language elements such as grammar and vocabulary. The implementation of skills and criteria tested in English National Exam should picture one whole complete package of language test as it should be that testing out students' language mastery. Yet, the English National Exam that once said to be focused on cognitive aspects but apparently not.

The test uses multiple choices and consists of fifty questions. There is unequal number distributions for the questions of each language competence. There are fifteen questions only in listening section and the rest 35 numbers are in the reading section. By 
having unequal number distributions for the test and incomplete language competence, the researcher could assume that the test should be reconsidered as a proficiency test. Whereon, the tests do not cover what we call as language mastery demands.

Nowadays, English proficiency is considered as an economic advantage at all (Sakka, Aswad, and Fajriani 2018). It is intensively becoming a basic skill needed for the entire workforce, in the same way that literacy has been evolved in the last two centuries from an elite privilege into a general requirement for informed citizenship, (Rao, 2016). A test is expected to measure the ability, knowledge, or performance individually. A test is an instrument that requires performance of the test-taker as well. The method used must be explicit and structured. Besides, a test is must be measurable.

Theoretically, this research is expected to give contribution and provide the explanation and the theory on National Exam that being applied for 5 years lately. Practically, the findings of this research can be used as a reference to facilitate the test-maker and future researcher in analyzing and measuring kinds of Exam.

\section{Literature Review Previous Studies}

Effendi and Suyudi (2017) concluded that National Exam gives negative washback to all related parties such as the parents, teachers and students themselves. It proved that Exams apparently only enhanced very minimum capacity of the target language of the test-taker. The students learning process in class was reportedly focused on the exam. The teachers agreed that it seemed they had misled the students from the main goals on language studying which was described on curriculum to graduation requirements. The reason was they want all students to graduate. Meanwhile, the parents faced different issue than the others, it was about economic situation. In which they had to prepare more budget to get their kids tutoring session for the exam.

Sutari (2017) pointed out that the test was only focused on receptive skills, listening and reading while in school the students were taught both receptive and productive skills. Yet, their language competence score was measured only on those competencies. It was negative washback to the whole process. Zubaidi and Novitasari (2015) found that students felt the National Exam cannot measure their competence as a whole. They even suggested changing the exam with progress-based assessment.

Previous studies above are related to National Exam, assessment, and analysis. Those studies measured different year of the exam yet still found a same thing. This study is different from studies above, it elaborates 5 year English National Exam on High Schools analyses and the students ability in Indonesia on taking the test. The researcher would like to review any changes made in each year test compared to the previous one, whether it is significant or not. Therefore, the researcher intended to conduct a research focus on National Exam analyses.

\section{Theoretical Framework}

Hakuta and Jacks (2009: 8-15) explains steps in conducting an assessment towards a test. Here are the steps:

\section{a. Planning the Assessment}

This section describes some general principles in analysing a test: 
The purpose of a test must be clear in order for valid interpretations to be made on the basis of the test scores.

- Defining the Construct

A second criterion for validity is a precise and explicit definition of the construct the test is intended to measure. In Indonesia nowadays we have Curriculum 2013 as the teaching standard rule which underlie the test specifications.

- Developing the Assessment Specifications

Assessment specifications define the test content and explain how that content will be assessed.

Domain of Knowledge and Skills: States are likely to have documented content standards for the subject area to be assessed. States may also provide performance standards and other documents that define the domain and their expectations for student achievement.

Number and Types of Items or Tasks: In general, all other things being equal, tests with more items will supply more reliable scores. Hakuta and Jacks (2009) suggests that the test-maker should making an effort to present the best options for task types that allow ELLs to show what they know and can do within the practical limits of the assessment program.

Relative Weights of Tasks and Skills: The weight of a task or content category is generally decided by the importance of the assessed task. In the test will be better to reduce a task that need more time to complete.

\section{b. Developing Test Items and Scoring Criteria}

- Matching the Task to the Purpose

Item writers and reviewers should work to ensure that all test items maintain specificity in their match to content guidelines.

- Defining Expectations

The criteria for the evaluation of the response should be made clear to the student.

- Writing Appropriate Directions

Design directions to maximize clarity and minimize the potential for confusion. Consider options for simplifying the language used for directions (see below), it will be more understandable if the instruction is (see Testing Accommodations).

- Using Accessible Language

Some general guidelines for using accessible language need to be considered, such as; use vocabulary that will be widely accessible to students; avoid colloquial and idiomatic expressions; keep sentence structures as simple as possible to express the intended meaning; avoid use of negatives and constructions utilizing.

- Presentation

For all assessments, test-makers should be aware of formatting issues. Fonts, font sizes, line breaks in paragraphs, and test directions should all receive a careful review.

\section{c. External Reviews of Test Materials}

Here are some questions need to consider in assessing and analyzing test: 
- Does each task match the purpose of the assessment and the assessment specifications?

- Are the directions for each task clear and appropriate?

- Is the task presented in clear and accessible language, free from idioms, and complex linguistic constructions?

- Are the formats of both the assessment and the response materials appropriate?

- Do the tasks and scoring criteria meet standards for fairness?

\section{METHOD}

The National Exam is still one of absorbed issues to discuss. The researcher bring the issue up because in a couple years there might be no more National Exam since the new minister is more likely to believe that Exams are conventional so the issue of abolishing it is heating up again. The researcher applied descriptive qualitative as the research design. She chose the latest 5 years English National Exam as the data. Initially, she outlined the dissimilarities of each of the exams conducted since 2015 until 2019. Later then, she explained how the tests are being measured before they are conducted. The researcher also analyzed if the questions tested were appropriate with the qualifications, criteria and the goals of each competences. The researcher applied the general method in assessing English test referred to the Hakuta and Jacks (2009) guidelines.

\section{FINDINGS AND DISCUSSION}

The government has conducted the national exam since 1970 called 'Ujian Negara' proposed by the Department of National Education to test the students' competence as the basis term for their graduation from high school as well as their continuity to university. The revision has been made as the era evolved. The government changed the system and the name of the exam 3 times until now. In the year of 1970 until 1982 'Ujian Negara' was changed with 'Ujian Sekolah'. At that time, the school was allowed to determine the students' graduation. It was a massive alteration since the previous system was regulated very strictly by the government.

The second change was in 1983, the exam was called 'EBTANAS' and lasted for 9 years. The assessment system for students' graduation was also being altered by combining both scores from the national exam and the test from school itself. Thereupon, the output seemed fair enough for all relevant parties such as teachers, government, parents and especially students. The last change was in the year of 2003, the government did not use the term 'EBTANAS' anymore but rather using 'Ujian Nasional' or in English 'National Exam' as the title. The system was also updated many times due to community demands, the students' needs to get passed. The latest system that is still ongoing combines the two scores of national exam and school's test and to use the average score as the final score for graduation score standard.

Meanwhile, the curriculum as the starting point of educational system in Indonesia has been revised 11 times since the first time it was conducted. The changes were made in the year of 1947, 1964, 1968, 1973, 1975, 1984, 1994, 1997, 2004, 2006 and 2013. Curriculum 2013 version has also been revised for several times until now and the latest revision was in 2018. The curriculum is still used until now in every school level. It is necessary to imply that the English national exam test making is actually not curriculum based. 
As we are fully aware that English is being learnt in Indonesia as a foreign language. Based on four main competences of English in Curriculum 2013, students are presumed to be able to understand, apply, analyze, process and provide all the factual, procedural and conceptual understanding about both language competences and skills in order to be able to use English as a foreign language properly. In Curriculum 2013, English is supposed to be mastered for both academic and non-academic purpose for the future, yet National Exam only focus on the cognitive comprehension. So, the researcher concludes that referring to the main focus of studying English, the National Exams from year 2015 until 2019 does not cover all goals in studying the language at all.

There are some parts in assessment specifications, first is about domain of knowledge and skills. There are two language competencies tested on English National Exam of 2015 until 2019, they are listening and reading, but reading marks the most. The test-makers seem focus on testing students' reading comprehension more than listening. Here is the breakdown of English National Exam questions through the year of 2015 until 2019:

Table 1.1. The National Exam Breakdown from Year 2015 - 2019

\begin{tabular}{|c|c|c|c|}
\hline \multicolumn{4}{|c|}{ THE ENGLISH NATIONAL EXAM FROM 2015 - 2019} \\
\hline Year & Test & Number & $\begin{array}{c}\text { Total } \\
\text { Question(s) }\end{array}$ \\
\hline \multirow{3}{*}{2015} & Listening & 1 to 15 & 15 \\
\hline & Vocabulary & 43 & 1 \\
\hline & Reading & 16 to 42,44 to 50 & 34 \\
\hline \multirow{3}{*}{2016} & Listening & 1 to 15 & 15 \\
\hline & Vocabulary & $27,30,39,42$ & 4 \\
\hline & Reading & $\begin{array}{l}16 \text { to } 26,28,29,31 \text { to } 38, \\
40,41,43 \text { to } 50\end{array}$ & 31 \\
\hline \multirow[b]{3}{*}{2017} & Listening & 1 to 15 & 15 \\
\hline & Vocabulary & $19,22,26,30,38,42$ & 6 \\
\hline & Reading & $\begin{array}{c}16 \text { to } 18,20,21,23 \text { to } 25, \\
27 \text { to } 29,31 \text { to } 37,39 \text { to } 41 \text {, } \\
43 \text { to } 50\end{array}$ & 29 \\
\hline \multirow{3}{*}{2018} & Listening & 1 to 15 & 15 \\
\hline & Vocabulary & $18,21,27,39,47$ & 5 \\
\hline & Reading & $\begin{array}{c}16,17,19,20,22 \text { to } 26,28 \\
\text { to } 38,40 \text { to } 46,48 \text { to } 50\end{array}$ & 30 \\
\hline \multirow{3}{*}{2019} & Listening & 1 to 15 & 15 \\
\hline & Vocabulary & $35,39,49$ & 3 \\
\hline & Reading & $\begin{array}{c}16 \text { to } 34,36 \text { to } 38,40 \text { to } 48, \\
\text { and } 50\end{array}$ & 32 \\
\hline
\end{tabular}


From 50 questions, 15 is for listening and the rest 35 is actually for reading session. But on several numbers in reading session, there are vocabulary tests inserted in which asking the students to find the synonym of an underlined word. However, the amount of questions given is not equal to every new exam held in every year. Even the difference between the total number of each session like listening, reading and vocabulary is not reasonable.

In the year of $2015,68 \%$ of 50 questions are reading comprehension test, $30 \%$ are listening and $2 \%$ which is 1 question for vocabulary by finding out the synonym which best described the underlined word based on the passage. It means that, in order to be able to get passed, the students only need to master reading skills and to have all their 34 answers on reading session correct. As Hakuta and Jacks (2009) said that tests with more items will supply more reliable scores, it means, to get a reliable result or final score, the number of the test should adequate to be assessed.

All three tests, listening, reading and vocabulary are not reliable. The researcher finds it so unrelatable to assess students' vocabulary mastery by only putting 1 question. Furthermore, the researcher also wonders what could be the best reason of inserting 1 type of such question in an exam with the national scale. Besides, the arrangement of the questions number for some language competences are compiled disorderly. It can make the students confused and lose focus on dealing with each skill. It will be better if the questions are arranged orderly and are compiled as a unit just like the listening section.

In 2016, as we can see from the table the number of listening test is still the same, on the other hand the test-maker put 4 numbers of vocabulary mastery test in the exam while the rest is reading comprehension test. There is no significant change of the previous English national exam to this 2016 version. Same case as the exam of year 2016 but 2017 was a little bit different. Though the total number of listening section is also 15, yet in this part of the test the test-maker added 2 more numbers of vocabulary mastery test and put each question to every last question of each sequence of a reading passage. In other words, there are several reading passages in the exam and each passage contains 3 or 4 questions. The vocabulary mastery questions are inserted among the reading comprehension test. Hence, except the last one of each passage of 2017 English exam got one vocabulary mastery question.

The researcher was assuming the number of questions distributed in 2018 exam will be proportionated. In fact, it is not. The language competences tested are still the same, they are listening, reading, and few vocabulary. In the test, the number of listening is 15,30 questions for reading and 5 for vocabulary. The researcher expected the test-makers to keep adding more vocabulary tests if they really meant to assess the students' vocabulary mastery. The amount of questions given was fewer than the previous exam. The researcher opined that dividing 50 numbers for 3 tests equally is better in order to get a valid measurement for each competence, for example 15 questions for listening section, another 15 questions for vocabulary mastery test as the second section and the rest 20 questions for reading comprehension test.

Surprisingly, the latest exam which had just been conducted in April 2019 was no different from the earlier tests. There was no new language competence test added, or equal distributed questions. In fact, the vocabulary questions were lesser than the previous ones.

The second domain skill in all these exams from year 2015 until 2019 was listening which contained four parts using monologues and dialogues. In the first line of listening section, the goal is well stated that the students are expected to show how well they understand the spoken English. It shows that the goal of listening section complies with the 
goal of listening skill in Curriculum 2013. The section is started with the simple part, one dialogue for one question. The narrator uses British accent, but the ones who speak in the dialogues or monologues sometimes use British or American accent.

Contrarily with the other section such as reading, the goal is not stated as the listening section is. It will be better if the goals for each section are stated before the questions part. In reading test, it will be better if it is started with simple transactional text. In fact, it is started with a long transactional text. The researcher concludes that the reading texts used are quite heavy for students to comprehend in the very first question for reading, it will take time in reading the text.

\section{CONCLUSION}

After conducting a research analysis, the researcher concludes that even in the 5 years of English National Exam year 2015 until 2019 there were still technical mistakes, grammatically uncorrect and so on. The test designs still not compatible with Curriculum that has been used in Indonesia. The Exams were focused more in reading comprehension rather than the other skills. The Exams were more likely not English tests yet English reading tests. For some parts, the test directions were unclear. They can lead the students to confusion. Then, the questions were compiled disorderly. Questions should be ordered from the easy to the difficult ones, instead the researcher found it arranged disorderly. Many questions and text used were not appropriate for high school level. The test-maker should be more careful in designing an English test and choosing the kind of text and questions, especially when it is used nationally for deciding national graduation, so that the students will not misunderstand the meaning.

\section{REFERENCES}

Alberts, René, Peter Hermans. (2010). The analysis of examination results as a prerequisite for improved teaching. 36th IAEA Annual Conference. Bangkok.

Brown, H. Douglas. (2006). Principles of Language Learning and Teaching $5^{\text {th }}$ Edition. New York: Pearson/Longman.

Effendi, Taufiq, Ichwan Suyudi. (2017). The Impacts of English National Examination in Indonesia. Atlantis Press, Volume 82, 236-239. 10.2991/conaplin-16.2017.52

Gay, L. R., Mills, Geoffrey E., and Airasian, Peter. (2006). Educational Research $8^{\text {th }}$ Edition: Competencies for Analysis and Applications. New York: McGrew Hill Book Company.

Hakuta, Kenji, Lee L. Jacks. (2009). Guidelines for the Assessment of English Language Learners. Stanford University: Educational Testing Service.

Kubiszyn, Tom, Gary D Borich. (1993). Educational Testing and Measurement. New York: Harper Collins College Publisher.

Rao, V. Chandra Sekhar. (2016). A Brief Study of English Language Proficiency : Employability. English for Specific Purposes World, Volume 17, Issue 49. www.esp-world.info. 
Sutari, Valentina Rizki. (2017). National Examination in Indonesia and Its Backwash Effects: Teachers' Perspectives. Atlantis Press, Volume 82,331-333.

Sakka, Wahyuni, Muhammad Aswad, and Fajriani Fajriani. 2018. "Enhancement of English Student Learning Results through Total Physical Response (TPR) Method." EDUVELOP (Journal of English Education and Development) 1 (2): 86-95. https://doi.org/10.31605/eduvelop.v1i2.31.

Zubaidi, Nanang, Budi Tiara Novitasari. (2014). Ideal vs Practice of Indonesian Senior High School National Exam of English. 10th Conference on Language Assessment and Curriculum.

https://www.researchgate.net/publication/263393377_Ideal_vs_Practice_of_Indon esian_Senior_High_School_National_Exam_of_English_Subject_Students'_Perce ption 